\title{
PENINGKATAN HASIL BELAJAR MATEMATIKA MENGGUNAKAN MODEL PEMBELAJARAN TALKING STICK
}

\author{
Dwi Ratmawati, S.Pd \\ MI Ma'arif Kapulogo \\ Email: dwiratmawati@gmail.com \\ Dhiya Ayu Tsamrotul Ihtiari, M.Pd \\ STAINU Purworejo \\ Email: tsamrotul.ihtiari@gmail.com
}

\begin{abstract}
The results of mathematics lessons of grade 4 students of MI Maarif Kapulogo Village, Kepil Wonosobo subdistrict can be said to be renddah. Based on the results of the interview obtained data on the average daily repeat value of students multiplication material and the division of numbers is 67.00 and students who can be said to complete is 6 students out of 10 students, then the percentage of completion of student learning is $62 \%$.

The research aims to know the process of mathematics learning and to know the improvement of learning outcomes in grade 4 students of MI Ma arif Kapulogo Kepil Wonosobo in the 2020/2021 school year after learning using Talking stick learning models.

This type of research is a class action research with 2 cycles and each cycle consists of 4 stages namely planning, implementation, observation and reflection. The subject of the study was a grade 4 student of MI Ma'arif Kapulogo with a total of 10 people. Collection using observation and test methods. Data analysis using descriptive analysis.

The results showed that the mathematics learning process using Talking stick learning model in grade 4 students of MI Ma'Arif Kapulogo Kepil Wonosobo in the 2020/2021 school year was carried out as many as two cycles and each cycle consisted of 2 meetings. Each cycle consists of four stages, namely planning, implementation, observation and reflection. The results showed that the average results of learning mathematics in pre-cycle was 57 with 50\% completedness. Then the average results of learning mathematics in the cycle increased to 70 with $70 \%$ completeness and in the second cycle the average results of mathematics learning increased to 85 with $90 \%$ completeness. Thus, the learning model of Talking stick approach can improve the results of mathematics learning students in grade IV MI Ma'arif Kapulogo District Kepil Wonosono Regency
\end{abstract}

Keywords: Learning Outcomes, Mathematics, Talking sticks.

\begin{abstract}
Abstrak
Hasil belajar matematika siswa kelas IV MI Maarif Desa Kapulogo Kecamatan Kepil Wonosobo dapat dikatakan renddah. Berdasarkan hasil wawancara tersebut diperoleh data rata-rata nilai ulangan harian siswa materi perkalian dan pembagian bilangan adalah 67,00 dan siswa yang dapat dikatakan tuntas adalah 6 siswa dari 10 siswa, maka persentase ketuntasan belajar siswa adalah $62 \%$.

Penelitian bertujuan mengetahui proses pembelajaran matematika dan mengetahui peningkatan hasil belajar pada siswa kelas IV MI Ma`arif Kapulogo Kepil Wonosobo
\end{abstract}


STAINU Purworejo: Jurnal As Sibyan

Jurnal Kajian Kritis Pendidikan Islam

Vol 4 No 1 Januari - Juni 2021

dan Manajemen Pendidikan Dasar

Homepage: https://ejournal.stainupwr.ac.id/

Email: sibyan.stainupwrj@gmail.com

E-ISSN: : 2599-2732

tahun pelajaran 2020/2021 setelah dilakukan pembelajaran menggunakan model pembelajaran Talking stick.

Jenis penelitian ini adalah penelitian tindakan kelas dengan 2 siklus dan masingmasing siklus terdiri 4 tahap yaitu perencanaan, pelaksanaan, pengamatan dan refleksi. Subjek penelitian adalah siswa kelas IV MI Ma arif Kapulogo dengan jumlah 10 orang. Pengumpulan menggunakan metode observasi dan tes. Analisis data menggunakan analisis deskriptif.

Hasil penelitian menunjukkan bahwa proses pembelajaran matematika menggunakan model pembelajaran Talking stick pada siswa kelas IV MI Ma`Arif Kapulogo Kepil Wonosobo tahun pelajaran 2020/2021 dilakukan sebanyak dua siklus dan setiap siklus terdiri dari 2 pertemuan. Setiap siklus terdiri dari empat tahap yaitu perencanaan, pelaksanaan, pengamatan dan refleksi. Hasil penelitian menunjukkan rata-rata hasil belajar matematika pada prasiklus adalah 57 dengan ketuntasan 50\%. Kemudian rata-rata hasil belajar matematika pada siklus meningkat menjadi 70 dengan ketuntasan $70 \%$ dan pada siklus II rata-rata hasil belajar metamtika meningkat menjadi 85 dengan ketuntasan 90\%. Dengan demikian model pembalajaran pendekatan Talking stick dapat meningkatkan hasil belajar matematika siswa kelas IV MI Ma`arif Kapulogo Kecamatan Kepil Kabupaten Wonosono.

Kata Kunci: Hasil Belajar, Matematika, Talking Stick

\section{A. PENDAHULUAN}

Pendidikan di era sekarang ini merupakan prioritas utama bagi suatu bangsa dan bagi Sumber Daya Manusia (SDM) itu sendiri. Suatu bangsa tidak akan maju jika SDM pada bangsa itu sendiri rendah. Maka dari itu, salah satu upaya untuk meningkatkan kualitas SDM yaitu melalui pendidikan. Pendidikan adalah proses pengembangan kemampuan dan perilaku manusia secara keseluruhan. Dengan demikian dapat dikatakan bahwa dengan adanya pendidikan, maka kualitas SDM akan dapat ditingkatkan. ${ }^{1}$

Pendidikan dasar merupakan titik paling penting dalam pendidikan karena di pendidikan dasar inilah individu mulai dibentuk dengan diberikan bekal-bekal ilmu pengetahuan yang nantinya akan menentukan langkah mereka selanjutnya. Permasalahan yang seringkali terjadi pada pendidikan dasar di Indonesia yaitu pada proses pembelajaran Guru SD/MI merupakan faktor utama penentu keberhasilan

\footnotetext{
${ }^{1}$ Dwi Siswoyo, dkk, Ilmu Pendidikan ( Yogyakarta: UNY Press, 2011), hlm. 54
} 
suatu proses pembelajaran. Salah satu indikator suatu proses pembelajaran dapat dikatakan berhasil yaitu dapat dilihat dari hasil belajar peserta didik. ${ }^{2}$

Snelbeker dalam Rusmono (2014) hasil belajar adalah perubahan atau kemampuan baru yang diperoleh siswa setelah melakukan perbuatan belajar. Hasil belajar peserta didik dapat dilihat melalui nilai yang diperoleh peserta didik, jika nilai hasil belajar peserta didik masih di bawah standar kriteria ketuntasan minimal (KKM) yang telah ditetapkan, maka dapat dikatakan bahwa hasil belajar peserta didik rendah dan suatu proses pembelajaran belum dapat dikatakan berhasil, dan sebaliknya. $^{3}$

Matematika adalah salah satu cabang ilmu yang diajarkan di sekolah dasar berdasarkan Kurikulum 2013 Mata pelajaran matematika SD/MI merupakan salah satu mata pelajaran yang berkaitan tentang logika mengenai sebuah konsep yang saling berhubungan satu sama lain. Selain itu, dalam suatu proses pembelajaran matematika supaya tidak terkesan membosankan oleh siswa, kegiatan belajar matematika juga dapat dilakukan dengan menggunakan permainan sehingga pembelajaran matematika menjadi menyenangkan

Sebelumnya peneliti juga sempat melakukan wawancara terhadap guru kelas IV MI Maaraif Kapulogo, ia mengatakan bahwa permasalahan yang ada adalah terdapat pada hasil belajar matematika siswa. Berdasarkan hasil wawancara tersebut diperoleh data rata-rata nilai ulangan harian siswa materi perkalian dan pembagian bilangan adalah 67,00 dan siswa yang dapat dikatakan tuntas adalah 6 siswa dari 10 siswa, maka persentase ketuntasan belajar siswa adalah $62 \%$.

Hal ini dapat terjadi dikarenakan oleh banyak faktor, antara lain karena media yang digunakan dalam mengajar, fasilitas pembelajaran kurang memadai, metode yang digunakan dalam mengajar. Selain permasalahan pada hasil belajar, berdasarkan hasil pengamatan yang dilakukan peneliti, menemukan permasalahan lain yaitu pada fasilitas pembelajaran. Beberapa buku ada yang rusak, meja-meja

2 Edi Susanto, Masalah yang dimiliki Sisw di sekolah dalam http://www.rumahbangsa.net/ 2014/07/masalah-yang-dihadapi-siswa-sekolah, dakses pada hari Senin, 17 Oktober 2020

${ }^{3}$ Rusmono, Strategi Pembelajaran dengan Problem Based Learning Itu Perlu. (Jakarta: Ghalia Indonesia, 2014). hlm. 8. 
STAINU Purworejo: Jurnal As Sibyan

Jurnal Kajian Kritis Pendidikan Islam

Vol 4 No 1 Januari - Juni 2021

dan Manajemen Pendidikan Dasar

Homepage: https://ejournal.stainupwr.ac.id/

Email: sibyan.stainupwrj@gmail.com

E-ISSN: : 2599-2732

kondisinya pun beberapa sudah tidak bagus dan banyak terdapat coretan-coretan di meja sehingga dapat mengganggu konsentrasi belajar siswa karena dapat membuat konsentrasi siswa lebih tertuju pada tulisan yang ada di meja daripada memperhatikan guru ketika proses pembelajaran berlangsung, dan ada beberapa tempat duduk siswa yang dapat dikatakan sudah kurang layak untuk dipakai. Hal ini dapat membahayakan bagi siswa dan membuat siswa menjadi kurang nyaman dalam belajar.

Berkaitan dengan permasalahan yang ada di atas, salah satu alternatif yang dapat digunakan guru untuk dapat meningkatkan hasil belajar siswa yaitu dengan mencoba menggunakan model baru, salah satunya yaitu melalui penerapan model pembelajaran talking stick untuk meningkatkan hasil belajar matematika siswa karena berdasarkan kenyataan yang ada bahwa salah satu karakteristik anak siswa SD adalah masih senang bermain Selain itu dengan menggunakan model talking stick, guru dapat mengetahui mana siswa yang sudah paham materi dan yang belum, yang kemudian guru menjelaskan kepada siswa yang masih kesulitan sehingga siswa tersebut menjadi paham, dengan demikian hasil belajar siswa dapat meningkat.

Model pembelajaran talking stick ini juga pernah dibuktikan oleh Rendi Lilit Iman Pambudi (2016). Penelitian tersebut menghasilkan temuan bahwa penerapan model pembelajaran talking stick dapat meningkatkan hasil belajar matematika siswa kelas IV SD N Suryodiningratan II. Sebelum diterapkannya tindakan, pada ulangan harian ada 13 siswa (62\%) yang mendapat nilai $\geq 65$ dan pada hasil pretes ada 11 siswa (52\%). Setelah diterapkannya tindakan, pada hasil tes siklus I ada 15 siswa (71\%) dan pada siklus II ada 18 siswa (86\%) dari seluruh siswa yang mendapat nilai $\geq 65$. $^{4}$

Melihat pentingnya hasil belajar dalam suatu pembelajaran untuk membantu siswa dalam mencapai ketuntasan belajar, maka kiranya perlu diadakan penelitian

\footnotetext{
${ }^{4}$ Rendi Lilit Iman Pambudi, Penerapan Model Pembelajaran Talking Stick Untuk Meningkatkan Hasil Belajar Matematika Pada Siswa Kelas IV SD Negeri Suryodiningratan Ii Tahun Ajaran 2015/2016, (Yogyakarta: PGSD-S1 Universitas Negeri Yogyakarta, 2016).
} 
STAINU Purworejo: Jurnal As Sibyan

Jurnal Kajian Kritis Pendidikan Islam

Vol 4 No 1 Januari - Juni 2021

dan Manajemen Pendidikan Dasar

Homepage: https://ejournal.stainupwr.ac.id/

Email: sibyan.stainupwrj@gmail.com

E-ISSN: : 2599-2732

untuk mengetahui lebih lanjut mengenai penerapan model pembelajaran talking stick untuk meningkatkan hasil belajar matematika.

Setelah diidentifikasi, dipilih dan dibatasi maka dapat dibuat rumusan masalah. Adapun rumusan masalah dalam penelitian ini adalah sebagai berikut: Bagaimana proses pembelajaran matematika menggunakan model pembelajaran talking stick pada siswa kelas IV MI Ma`Arif Kapulogo kepil Wonosobo tahun pelajaran 2020/2021? Bagaimana peningkatan hasil belajar pada siswa kelas IV MI Ma`Arif Kapulogo Kepil Wonosobo tahun pelajaran 2020/2021 setelah dilakukan pembelajaran menggunakan model pembelajaran talking stick?

\section{B. METODOLOGI}

Dalam penelitian ini peneliti menggunakan jenis Penelitian Tindakan Kelas (PTK). Penelitian Tindakan Kelas adalah penelitian yang dilakukan oleh guru kelas atau di sekolah tempat ia mengajar dengan penekanan pada penyempurnaan atau peningkatan proses dan praksis pembelajaran. ${ }^{5}$ Pelaksanaan penelitian tindakan meliputi 4 langkah yaitu perencanaan (planning), tindakan/kegiatan (action), pengamatan (observation), dan refleksi (reflection). Setiap langkah pelaksanaan termuat dalam suatu siklus. Berikut ini adalah gambaran keempat langkah dalam PTK.

Subjek penelitian adalah siswa kelas IV MI Ma`Arif Kapulogo Kepil Wonosobo Tahun Pelajaran 2020/2021 sebanyak 10 orang. Sedangkan objek penelitiannya adalah hasil brlajar matematika melalui pendekatan pembelajaran talking stick pada materi penafsiran.

Teknik pengumpulan data yang digunakan adalah:

\section{Observasi}

Lembar observasi yang digunakan dalam penelitian ini adalah lembar observasi yang digunakan untuk mengamati penerapan model pembelajaran talking stick.

${ }^{5}$ Suharsimi Arikunto. Penelitian Tindakan Kelas. (Jakarta: Rineka Cipta., 2010). Hlm. 135 


\section{dan Manajemen Pendidikan Dasar}

Homepage: https://ejournal.stainupwr.ac.id/

Email: sibyan.stainupwrj@gmail.com

E-ISSN: : 2599-2732

2. Tes

Tes digunakan untuk memperoleh gambaran pemahaman dan prestasi belajar siswa. Tes ini menggunakan soal evaluasi yang telah disusun berdasarkan materi yang diberikan.

Selanjutnya data yang dianalisis adalah data yang diperoleh selama proses penelitian yaitu dari hasil tes dan lembar observasi. Untuk menghitung tes akhir siklus, peneliti memeriksa setiap jawaban siswa dan memberi skor. Setelah memberi skor pada jawaban siswa, peneliti menghitung rerata dengan ketentuan sebagai berikut: ${ }^{6}$

$$
\text { Nilai Rata-rata }=\frac{\text { jumlah skor yang diperoleh }}{\text { jumlah siswa }}
$$

Untuk menghitung persentase hasil dari lembar observasi dan tes setiap siklus dengan menggunakan rumus sebagai berikut: ${ }^{7}$

$$
\text { Persentase }=\frac{\text { jumlah skor yang diperoleh }}{\text { jumlah skor ideal }} \times 100 \%
$$

Data yang bersifat kuantitatif diubah menjadi data yang bersifat kualitatif dengan pedoman seperti yang terlihat pada tabel 1 berikut $^{8}$

Tabel 1

Kriteria Penskoran Keaktifan

\begin{tabular}{|c|c|}
\hline Persentase & Kriteria \\
\hline $90-100$ & Sangat Baik \\
\hline $80-89$ & Baik \\
\hline $65-79$ & Cukup \\
\hline $55-64$ & Kurang \\
\hline$<55$ & Kurang Sekali \\
\hline
\end{tabular}

6 Mulyasa. Pengembangan Implementasi Kurikulum. (Bandung: PT. Remaja Karyaja Rosda Karya, 2013), hlm. 105.

${ }^{7}$ Sugiyono, Metode Penelitian Pendidika ( Bandung: Alfabeta, 2015), hlm. 95.

${ }^{8}$ Mulyasa. Pengembangan Implementasi Kurikulum. (Bandung: PT. Remaja Karyaja Rosda Karya, 2013), hlm. 115 
STAINU Purworejo: Jurnal As Sibyan

Jurnal Kajian Kritis Pendidikan Islam

dan Manajemen Pendidikan Dasar

Homepage: https://ejournal.stainupwr.ac.id/

Email: sibyan.stainupwrj@gmail.com

E-ISSN: : 2599-2732

\section{HASIL DAN PEMBAHASAN}

Data dalam penelitian ini diperoleh dari instrumen yang terdiri dari lembar observasi keaktifan dan soal tes evaluasi. Observasi dilakukan setiap kegiatan pembelajaran dan tes evaluasi dilakukan setiap akhir siklus. Penelitian tindakan kelas ini dilaksanakan dalam 2 siklus. Siklus pertama dan kedua terdiri dari 2 kali pertemuan dengan jumlah alokasi waktu $2 \times 35$ menit dengan pertemuan ketiga diadakan tes akhir siklus I dan II dengan alokasi waktu $2 \times 35$ menit. Setiap siklus terdiri dari 4 tahapan yaitu perencanaan, tindakan, pengamatan, dan refleksi.

1. Deskripsi Kondisi Awal

Penelitian dilakukan di kelas IV MI Ma'arif Kapulogo Kepil Wonosobo Tahun Pelajaran 2020/2021 dengan jumlah siswa 10 orang pada pembelajaran matematika pada dengan penaksiran operasi hitung. Berdasarkan hasil observasi yang telah dilakukan didapatkan berbagai permasalahan dalam pembelajaran. Rendahnya hasil belajar metamtika dipengaruhi oleh beberapa faktor, yaitu kurangnya tingkat konsentrasi siswa dalam mengikuti pembelajaran, selain itu adalah penggunaan model pembelajaran yang diterapkan oleh guru. Pada saat pembelajaran berlangsung guru hanya menggunakan pembelajaran yang konvesional, hal ini yang menyebabkan siswa kurang bisa memaknai pembelajaran matematika dan hasil embelajaran matematika menjadi rendah. Hasil belajar matematika kelas 4 MI Ma`Arif Kapulogo Kepil Wonosobo Tahun Pelajaran 2020/2021 sebelum tindakan masih rendah. Hal ini dapat hasil nilai pembelajaran matematika seperti dibawah ini.

Tabel 2

Hasil Belajar Matematika pada Pra Siklus

\begin{tabular}{|c|l|c|c|}
\hline No & Nama & Nilai & Keterangan \\
\hline 1 & Siswa1 & 40 & Belum tuntas \\
\hline 2 & Siswa2 & 70 & Tuntas \\
\hline 3 & Siswa3 & 70 & Tuntas \\
\hline 4 & Siswa4 & 70 & Tuntas \\
\hline 5 & Siswa5 & 70 & Tuntas \\
\hline 6 & Siswa6 & 30 & Belum tuntas \\
\hline
\end{tabular}


STAINU Purworejo: Jurnal As Sibyan Jurnal Kajian Kritis Pendidikan Islam

\section{dan Manajemen Pendidikan Dasar}

Homepage: https://ejournal.stainupwr.ac.id/

Email: sibyan.stainupwrj@gmail.com

E-ISSN: : 2599-2732

\begin{tabular}{|c|l|c|c|}
\hline 7 & Siswa7 & 50 & Belum tuntas \\
\hline 8 & Siswa8 & 80 & Tuntas \\
\hline 9 & Siswa9 & 30 & Belum tuntas \\
\hline 10 & Siswa10 & 60 & Belum tuntas \\
\hline Rata-rata & 57 & \\
\hline \multicolumn{2}{|l|}{ Nilai tertinggi } & 30 & \\
\hline \multicolumn{2}{|l|}{ Nilai terendah } & 70 & \\
\hline \multicolumn{2}{|l|}{ KKM } & $50 \%$ & \\
\hline \multicolumn{2}{|l|}{ Ketuntasan }
\end{tabular}

Berdasarkan Tabel 21 diketahui bahwa hasil belajar matematika kelas IV MI Ma'arif Kapulogo Kepil Wonosobo Tahun Pelajaran 2020/2021 tergolong rendah dengan rata-rata hanya 57 dan masih dibawah KKM yaitu 70. Persentase ketuntasan pembelajaran yang tercapai masih rendah yaitu 50\% dari jumlah seluruh siswa.

2. Deskripsi Siklus I

Pembelajaran pada siklus I dilaksanakan dalam 2 pertemuan dengan alokasi waktu $4 \times 35$ menit. Pertemuan pertama digunakan untuk membahas materi pembulatan kesatuan, puluhan, ratusan dan ribuan terdekat dan pertemuan kedua digunakan untuk membahas materi pembulatan hasil pengukuran panjang dan berat.

a. Perencanaan

Pada tahap perencanaan, tindakan-tindakan yang dilakukan adalah sebagai berikut:

1) Menyiapkan perangkat pembelajaran yang akan digunakan, yaitu Silabus dan Rencana Pelaksanaan Pembelajaran (RPP).

2) Menyiapkan instrumen Lembar Keterlaksanaan Pendekatan Pembelajaran talking stick dan Lembar Observasi Keaktifan untuk mengetahui keaktifan pada tahap tindakan atau akhir siklus I.

3) Menyusun soal evaluasi berdasarkan indikator belajar pada materi yang telah disampaikan. Soal tes diberikan pada pertemuan 3 atau diakhir siklus I.

4) Mengadakan pembagian tugas antara peneliti dan observer. Peneliti sebagai pelaksana tindakan dan guru matematika kelas IV sebagai observer I yang 
bertugas sebagai observer keaktifan dan mengisi lembar keterlaksanaan pendekatan talking stick.

b. Pelaksanaan

Pada tahap ini merupakan implementasi dari tahap perencanaan. Berikut ini adalah rincian kegiatan tiap pertemuan.

\section{1) Pertemuan 1}

Pertemuan pertama dilaksanakan pada hari Senin, 30 November 2020. Materi pembelajaran pada pertemuan ini adalah pembulatan bilangan. Kegiatan pembelajaran terdiri dari pendahuluan, kegiatan inti, dan penutup.

Kegiatan pendahuluan diawali dengan guru memberikan salam dan mengajak berdo'a menurut agama dan keyakinan masing-masing, Kemudian guru mlakukan komunikasi tentang kehadiran siswa. Guru memberi motivasi dan kegiatan untuk menambah konsentrasi siswa. Guru menyiapkan fisik dan psikis anak dalam mengawali kegiatan pembelajaran serta menyapa anak. Guru memberitahukan penggunaan metode talking stick dalam pembelajaran kali ini

Pada kegiatan inti guru membentuk kelompok dilanjutkan dengan guru menyampaikan materi kemudian memberi kesempatan kepada kelompok untuk membaca dan mempelajari materi. Siswa mengamati dan guru menjelaskan tentang pembulatan suatu bilangan. Guru memberikan kesempatan kepada siswa untuk bertanya dan guru menjelaskan pertanyaan siswa. Siswa diminta mencoba berdiskusi dengan temannya tentang pembulatan bilangan. Guru meminta siswa menutup buku dan menyatakan bahwa siswa telah paham tentang pembulatan bilangan. Pada tahap penerapan metode talking stick guru mengambil tongkat dan memberikan kepada salah satu siswa, setelah itu guru memberikan pertanyaan dan siswa yang memegang tongkat harus menjawab. Demikian seterusnya sampai sebagaian besar siswa mendapat bagian untuk menjawab pertanyaan dari guru. Siswa mempresentasikan secara lisan kepada teman-temanya tentang pembulatan suatu bilangan. Siswa menyampaikan manfaat belajar pembulatan suatu bilangan yang dilakukan secara lisan di depan teman dan guru. 
Pada kegiatan penutup guru memberikan penguatan materi dan kesimpulan dari pembulatan suatu bilangan dan dilanjutkanu mengapresiasi hasil kerja siswa dan memberikan motivasi. Guru menyampaikan pesan moral hari ini dengan bijak dan pembelajaran diakHiri dengan salam dan do'a penutup.

2) Pertemuan 2

Pertemuan kedua dilaksanakan pada hari Selasa tanggal 1 Desember 2020. Materi pembelajaran pada pertemuan ini adalah pembulatan pengukuran panjang dan berat.

Kegiatan pendahuluan diawali dengan guru memberikan salam dan mengajak berdo'a menurut agama dan keyakinan masing-masing, Kemudian guru melakukan komunikasi tentang kehadiran siswa. Guru memberi motivasi dan kegiatan untuk menambah konsentrasi siswa. Guru menyiapkan fisik dan psikhis anak dalam mengawali kegiatan pembelajaran serta menyapa anak. Guru memberitahukan penggunaan metode talking stick dalam pembelajaran kali ini

Pada kegiatan inti guru membentuk kelompok dilanjutkan dengan guru menyampaikan materi kemudian memberi kesempatan kepada kelompok untuk membaca dan mempelajari materi. Siswa mengamati dan guru menjelaskan tentang pembulatan suatu bilangan. Guru memberikan kesempatan kepada siswa untuk bertanya dan guru menjelaskan pertanyaan siswa. Siswa diminta mencoba berdiskusi dengan temannya tentang pembulatan bilangan. Guru meminta siswa menutup buku dan menyatakan bahwa siswa telah paham tentang pembulatan bilangan. Pada tahap penerapan metode talking stick guru mengambil tongkat dan memberikan kepada salah satu siswa, setelah itu guru memberikan pertanyaan dan siswa yang memegang tongkat harus menjawab. Demikian seterusnya sampai sebagaian besar siswa mendapat bagian untuk menjawab pertanyaan dari guru. Siswa mempresentasikan secara lisan kepada teman-temanya tentang pembulatan suatu bilangan. Siswa menyampaikan manfaat belajar pembulatan suatu bilangan yang dilakukan secara lisan di depan teman dan guru.

Pada kegiatan penutup guru memberikan penguatan materi dan kesimpulan dari pembulatan suatu bilangan dan dilanjutkanu mengapresiasi hasil kerja siswa 
STAINU Purworejo: Jurnal As Sibyan

Jurnal Kajian Kritis Pendidikan Islam

dan Manajemen Pendidikan Dasar

Homepage: https://ejournal.stainupwr.ac.id/

Email: sibyan.stainupwrj@gmail.com

E-ISSN: : 2599-2732

dan memberikan motivasi. Guru menyampaikan pesan moral hari ini dengan bijak dan pembelajaran diakhiri dengan salam dan do'a penutup.

c. Pengamatan

Pembelajaran pada siklus I telah dilaksanakan $2 \times$ pertemuan. Selama pembelajaran tersebut juga dilakukan observasi. Adapun hasil observasi keaktifan belajar siswa pada siklus I tersaji pada tabel berikut.

Tabel 3

Keaktifan Siswa pada Siklus I

\begin{tabular}{|c|c|c|c|}
\hline \multirow[b]{2}{*}{ No } & \multirow[b]{2}{*}{ Hal Yang Diamati } & \multicolumn{2}{|c|}{ Siklus I } \\
\hline & & $\begin{array}{l}\text { Pertemuan } \\
1 \\
\text { (Jml anak) }\end{array}$ & $2^{\text {Pertemuan }}$ \\
\hline 1 & Antusiasme siswa saat apersepsi & 8 & 9 \\
\hline 2 & $\begin{array}{l}\text { Perhatian siswa terhadap guru pada saat } \\
\text { penyampaian materi }\end{array}$ & 7 & 7 \\
\hline 3 & Keaktifan siswa dalam bertanya & 1 & 3 \\
\hline 4 & Keaktifan siswa dalam menjawab pertanyaan & 4 & 8 \\
\hline 5 & $\begin{array}{l}\text { Interaksi siswa saat melakukan diskusi secara } \\
\text { berkelompok }\end{array}$ & 1 & 4 \\
\hline 6 & Ketertiban saat mengikuti proses pembelajaran & 9 & 8 \\
\hline & Rata-rata keaktifan (\%) & $50 \%$ & $65 \%$ \\
\hline
\end{tabular}

Berdasarkan Tabel 3 diketahui pada siklus I pertemuan 1 siswa mulai aktif dalam belajar. Keaktifan siklus I pertemuan mencapai persentase 50\% (rendah), kemudian meningkat menjadi 65\% pada siklus I pertemuan 2.

Adapun hasil belajar siswa pada setiap pertemuan pembelajaran pada siklus I tersaji pada tabel berikut.

Tabel 4

Hasil Belajar Matematika Siklus I

\begin{tabular}{|c|l|c|l|}
\hline No & \multicolumn{1}{|c|}{ Nama } & Nilai & \multicolumn{1}{|c|}{ Keterangan } \\
\hline 1 & Siswa1 & 60 & Belum tuntas \\
\hline 2 & Siswa2 & 80 & Tuntas \\
\hline 3 & Siswa3 & 80 & Tuntas \\
\hline 4 & Siswa4 & 80 & Tuntas \\
\hline
\end{tabular}


STAINU Purworejo: Jurnal As Sibyan Jurnal Kajian Kritis Pendidikan Islam

\section{dan Manajemen Pendidikan Dasar}

Homepage: https://ejournal.stainupwr.ac.id/

Email: sibyan.stainupwrj@gmail.com

E-ISSN: : 2599-2732

\begin{tabular}{|l|l|l|l|}
\hline 5 & Siswa5 & 80 & Tuntas \\
\hline 6 & Siswa6 & 40 & Belum tuntas \\
\hline 7 & Siswa7 & 70 & Tuntas \\
\hline 8 & Siswa8 & 90 & Tuntas \\
\hline 9 & Siswa9 & 50 & Belum tuntas \\
\hline 10 & Siswa10 & 70 & Tuntas \\
\hline \multicolumn{2}{|l|}{ Rata-rata } & 90 & \\
\hline \multicolumn{2}{|l|}{ Nilai tertinggi } & 40 & \\
\hline \multicolumn{2}{l}{ Nilai terendah } & 70 & \\
\hline \multicolumn{2}{|l|}{ KKM } & $70 \%$ & \\
\hline \multicolumn{2}{l}{ Ketuntasan }
\end{tabular}

Persentase hasil belajar matematika siswa siklus I, siswa yang telah mencapai

Kriteria Ketuntasan Minimal (KKM) sebesar 70\% dalam kriteria cukup dengan rata-rata nilai 70 .

d. Refleksi

Berdasarkan hasil pengamatan peneliti dibantu observer pada siklus I dapat diketahui bahwa.

1. Sebagian siswa kurang aktif dalam diskusi, yang aktif hanya siswa tertentu.

2. Ketika guru menjelaskan masih ada siswa yang sibuk sendiri sehingga tidak memperhatikan penjelasan guru.

3. Siswa masih malu untuk menjawab pertanyaan dari guru.

4. Siswa masih malu menyampaikan ide maupun pertanyaan kepada guru

5. Siswa masih malu untuk bertanya mengenai materi yang belum dipahami.

Berdasarkan hasil analisis data observasi dan tes pada siklus I, diperoleh rerata kemampuan keaktifan 65\% dengan kategori cukup dan persentase hasil belajar matematika siswa yang telah mencapai Kriteria Ketuntasan Minimal (KKM) sebesar 70\% dalam kriteria cukup dengan rata-rata nilai 70. Sehingga hasil yang diperoleh belum memenuhi indikator keberhasilan, maka penelitian dilanjutkan ke siklus II. Sehingga terdapat beberapa hal yang perlu diperbaiki untuk rencana tindakan pada siklus II 
Pada siklus 1 masih terdapat beberapa siswa yang belum aktif dalam pembelajaran dan sebagian siswa berbicara sendiri pada saat proses pembelajaran. Hal ini juga menjadi pemasalahan sendiri yang harus diatasi pada pembelajaran siklus II.

Untuk menanggulangi permasalahan pada siklus I pada pembelajaran siklus II peneliti akan mengkondisikan agar pembelajaran berjalan lancar, memberi reward kepada siswa yang berprestasi dan melakukan pertukaran tempat duduk pada waktu pembelajaran maupun diskusi.

3. Deskripsi Siklus II

Pada penelitian tindakan kelas siklus II ini tidak berbeda jauh dengan siklus I, terdiri dari 2 pertemuan dengan alokasi waktu $4 \times 35$ menit. Pada pertemuan pertama dan kedua digunakan untuk pemberian materi menggunakan model pembelajaran talking stick. Pada peremuan I siklus II membahas materi menafsir hasil penjumlahan dan pengurangan sedangkan ada siklus II membahas materi menaksir hasil perkalian dan pembagian.

a. Perencanaan

Berdasarkan pengamatan dan refleksi pada siklus I, peneliti melakukan perbaikan pada siklus II. Pada tahapan ini dilakukan berbagai persiapan dan perencanaan sebagai berikut:

1) Menyiapkan perangkat pembelajaran yang akan digunakan, yaitu Rencana Pelaksanaan Pembelajaran (RPP). Disamping itu evaluasi siklus II.

2) Menyiapkan instrumen Lembar Keterlaksanaan Pendekatan Pembelajaran talking stick, Lembar Observasi Keaktifan untuk mengetahui kemampuan keaktifan pada tahap tindakan atau akhir siklus II.

3) Menyusun soal evaluasi berdasarkan indikator belajar pada materi yang telah disampaikan. Soal evaluasi diberikan di akhir siklus II.

4) Untuk mengatasi siswa yang belum aktif maupun berbicara sendiri pada saat pembelajaran pada siklus II, diberikan motivasi dan arahan agar mengikuti pembelajaran dengan baik. Kepada siswa yang belum aktif guru menyarankan agar pada pertemuan berikutnya bisa lebih baik dalam mengikuti pembelajaran. 
STAINU Purworejo: Jurnal As Sibyan

Jurnal Kajian Kritis Pendidikan Islam

Vol 4 No 1 Januari - Juni 2021

dan Manajemen Pendidikan Dasar

Homepage: https://ejournal.stainupwr.ac.id/

Email: sibyan.stainupwrj@gmail.com

E-ISSN: : 2599-2732

Bagi siswa yang bicara sendiri guru memberikan arahan agar siswa tidak melakukan lagi karena akan mengganggu kelancaran kegiatan pembelajaran.

5) Peneliti juga memberikan motivasi kepada siswa. Memberi arahan, memberikan sanksi kepada siswa yang tidak tertib, memberikan reward kepada siswa yang berprestasi, melakukan petukaran tempat dusuk selama pembelajaran maupun diskusi kelompok. Hal ini dilakukan agar siswa agar dapat mengikuti pembelajaran dengan tertib sehingga akan meningkatkan hasil matematikanya.

b. Pelaksanaan

1) Pertemuan 1

Pertemuan pertama dilaksanakan pada hari Rabu, 2 Desember 2020. Materi pembelajaran pada pertemuan ini adalah menaksir hasil penjumlahan dan pengurangan. Kegiatan pembelajaran terdiri dari pendahuluan, kegiatan inti, dan penutup.

Kegiatan pendahuluan diawali dengan guru memberikan salam dan mengajak berdo'a menurut agama dan keyakinan masing-masing, Kemudian guru mlakukan komunikasi tentang kehadiran siswa. Guru memberi motivasi dan kegiatan untuk menambah konsentrasi siswa. Guru menyiapkan fisik dan psikhis anak dalam mengawali kegiatan pembelajaran serta menyapa anak. Guru memberitahukan penggunaan metode talking stick dalam pembelajaran kali ini

Pada kegiatan inti guru membentuk kelompok dilanjutkan dengan guru menyampaikan materi kemudian memberi kesempatan kepada kelompok untuk membaca dan mempelajari materi. Siswa mengamati dan guru menjelaskan tentang pembulatan suatu bilangan. Guru memberikan kesempatan kepada siswa untuk bertanya dan guru menjelaskan pertanyaan siswa. Siswa diminta mencoba berdiskusi dengan temannya tentang pembulatan bilangan. Guru meminta siswa menutup buku dan menyatakan bahwa siswa telah paham tentang pembulatan bilangan Pada tahap penerapan metode talking stick guru mengambil tongkat dan memberikan kepada salah satu siswa, setelah itu guru memberikan pertanyaan dan siswa yang memegang tongkat harus menjawab. Demikian seterusnya sampai sebagaian besar siswa mendapat bagian untuk menjawab pertanyaan dari guru. 
STAINU Purworejo: Jurnal As Sibyan

Jurnal Kajian Kritis Pendidikan Islam

Vol 4 No 1 Januari - Juni 2021

dan Manajemen Pendidikan Dasar

Homepage: https://ejournal.stainupwr.ac.id/

Email: sibyan.stainupwrj@gmail.com

E-ISSN: : 2599-2732

Siswa mempresentasikan secara lisan kepada teman-temanya tentang pembulatan suatu bilangan. Siswa menyampaikan manfaat belajar pembulatan suatu bilangan yang dilakukan secara lisan di depan teman dan guru.

Pada kegiatan penutup guru memberikan penguatan materi dan kesimpulan dari pembulatan suatu bilangan dan dilanjutkanu mengapresiasi hasil kerja siswa dan memberikan motivasi. Guru menyampaikan pesan moral hari ini dengan bijak dan pembelajaran diakhiri dengan salam dan do'a penutup.

2) Peremuan 2

Pertemuan kedua dilaksanakan pada hari Kamis, 3 Desember 2020. Materi pembelajaran pada pertemuan ini adalah menaksir hasil perkalian dan pembagian. Kegiatan pembelajaran terdiri dari pendahuluan, kegiatan inti, dan penutup.

Kegiatan pendahuluan diawali dengan guru memberikan salam dan mengajak berdo'a menurut agama dan keyakinan masing-masing, Kemudian guru mlakukan komunikasi tentang kehadiran siswa. Guru memberi motivasi dan kegiatan untuk menambah konsentrasi siswa. Guru menyiapkan fisik dan psikhis anak dalam mengawali kegiatan pembelajaran serta menyapa anak. Guru memberitahukan penggunaan metode talking stick dalam pembelajaran kali ini

Pada kegiatan inti guru membentuk kelompok dilanjutkan dengan guru menyampaikan materi kemudian memberi kesempatan kepada kelompok untuk membaca dan mempelajari materi. Siswa mengamati dan guru menjelaskan tentang pembulatan suatu bilangan. Guru memberikan kesempatan kepada siswa untuk bertanya dan guru menjelaskan pertanyaan siswa. Siswa diminta mencoba berdiskusi dengan temannya tentang pembulatan bilangan. Guru meminta siswa menutup buku dan menyatakan bahwa siswa telah paham tentang pembulatan bilangan Pada tahap penerapan metode talking stick guru mengambil tongkat dan memberikan kepada salah satu siswa, setelah itu guru memberikan pertanyaan dan siswa yang memegang tongkat harus menjawab. Demikian seterusnya sampai sebagaian besar siswa mendapat bagian untuk menjawab pertanyaan dari guru. Siswa mempresentasikan secara lisan kepada teman-temanya tentang pembulatan 
STAINU Purworejo: Jurnal As Sibyan

Jurnal Kajian Kritis Pendidikan Islam

dan Manajemen Pendidikan Dasar

Homepage: https://ejournal.stainupwr.ac.id/

Email: sibyan.stainupwrj@gmail.com

E-ISSN: : 2599-2732

suatu bilangan. Siswa menyampaikan manfaat belajar pembulatan suatu bilangan yang dilakukan secara lisan di depan teman dan guru.

Pada kegiatan penutup guru memberikan penguatan materi dan kesimpulan dari pembulatan suatu bilangan dan dilanjutkanu mengapresiasi hasil kerja siswa dan memberikan motivasi. Guru menyampaikan pesan moral hari ini dengan bijak dan pembelajaran diakhiri dengan salam dan do'a penutup.

c. Pengamatan

Berikut ini akan dipaparkan data-data hasil penelitian pada siklus II

Tabel 5

Keaktifan Siswa pada Siklus I

\begin{tabular}{|r|l|c|c|}
\hline \multirow{2}{*}{ No } & \multicolumn{1}{|c|}{ Hal Yang Diamati } & \multicolumn{2}{c|}{ Siklus II } \\
\cline { 3 - 4 } & \multicolumn{1}{|c|}{$\begin{array}{c}\text { Pertemuan 1 } \\
\text { (Jml anak) }\end{array}$} & $\begin{array}{c}\text { Pertemuan 2 } \\
\text { (Jml anak) }\end{array}$ \\
\hline 1 & Antusiasme siswa saat apersepsi & 9 & 10 \\
\hline 2 & $\begin{array}{l}\text { Perhatian siswa terhadap guru pada saat } \\
\text { penyampaian materi }\end{array}$ & 10 & 10 \\
\hline 3 & Keaktifan siswa dalam bertanya & 7 & 8 \\
\hline 4 & $\begin{array}{l}\text { Keaktifan siswa dalam menjawab } \\
\text { pertanyaan }\end{array}$ & 10 & 5 \\
\hline 5 & $\begin{array}{l}\text { Interaksi siswa saat melakukan diskusi } \\
\text { secara berkelompok }\end{array}$ & 5 & 10 \\
\hline 6 & $\begin{array}{l}\text { Ketertiban saat mengikuti proses } \\
\text { pembelajaran }\end{array}$ & 9 & $88,3 \%$ \\
\hline & Rata-rata keaktifan (\%) & $83,3 \%$ & 5 \\
\hline
\end{tabular}

Berdasarkan Tabel 5 diketahui pada siklus II pertemuan 1 siswa mulai aktif dalam belajar. Keaktifan siklus II pertemuan 1 mencapai persentase 83,3\% (baik), kemudian meningkat menjadi 88,3\% pada siklus II pertemuan 2.

Adapun hasil belajar matematika pada siklus II adalah sebagai berikut:

Tabel 6

Hasil Belajar Matematika Siklus II

\begin{tabular}{|c|c|c|c|}
\hline No & \multicolumn{1}{|c|}{ Nama } & Nilai & Keterangan \\
\hline 1 & Siswa1 & 70 & Tuntas \\
\hline 2 & Siswa2 & 100 & Tuntas \\
\hline
\end{tabular}


STAINU Purworejo: Jurnal As Sibyan Jurnal Kajian Kritis Pendidikan Islam

dan Manajemen Pendidikan Dasar

Homepage: https://ejournal.stainupwr.ac.id/

Email: sibyan.stainupwrj@gmail.com

E-ISSN: : 2599-2732

\begin{tabular}{|c|l|c|l|}
\hline 3 & Siswa3 & 90 & Tuntas \\
\hline 4 & Siswa4 & 90 & Tuntas \\
\hline 5 & Siswa5 & 100 & Tuntas \\
\hline 6 & Siswa6 & 70 & Tuntas \\
\hline 7 & Siswa7 & 90 & Tuntas \\
\hline 8 & Siswa8 & 60 & Tuntas \\
\hline 9 & Siswa9 & 80 & Tuntas \\
\hline 10 & Siswa10 & 85 & \\
\hline Rata-rata & 100 & \\
\hline Nilai tertinggi & 60 & \\
\hline \multicolumn{2}{|l|}{ Nilai terendah } & 70 & \\
\hline \multicolumn{2}{|l|}{ KKM } & $90 \%$ & \\
\hline \multicolumn{2}{|l|}{ Ketuntasan }
\end{tabular}

Persentase hasil belajar matematika siswa siklus II, siswa yang telah mencapai Kriteria Ketuntasan Minimal (KKM) sebesar 90\% dalam kriteria baik dengan rata-rata nilai 85

d. Refleksi

Berdasarkan observasi dan evaluasi selama tahap pelaksanaan pada siklus II, hasil yang diperoleh sudah memenuhi indikator keberhasilan. Sehingga dapat diketahui bahwa siswa dapat menerima pembelajaran dengan pendekatan talking stick dan siklus dihentikan.

\section{Pembahasan}

Penelitian ini dilakukan di Kelas 4 MI Ma`Arif Desa Kapulogo Tahun Pelajaran 2020/2021 yang bertujuan untuk meningkatkan keaktifan dan prestasi belajar matematika. Dari hasil penelitian menunjukkan bahwa pendekatan talking stick dapat meningkatkan keaktifan dan hasil belajar matematika. Hal tersebut dapat dilihat dari observasi dan soal evaluasi siklus I dan II.

Hasil pengamatan keaktifan siswa dengan pembelajaran pendekatan talking stick pada siklus I, diperoleh persentase rerata keaktifan berdasarkan lembar observasi sebesar 65\% dalam kriteria cukup dan siswa yang telah mencapai Kriteria Ketuntasan Minimal (KKM) sebesar 70\% dalam kriteria cukup dengan rata-rata 
nilai 70. Pembelajaran pada siklus I belum berjalan dengan baik karena sebagian siswa belum memperhatikan dan belum mengikuti pembelajran dengan tertib. Siswa juga masih ragu untuk menjawab pertanyaan-pertanyaan dari peneliti dan belum berani memberikan pendapat. Saat berdiskusi beberapa siswa masih cenderung pasif. Ada siswa yang sibuk sendiri ketika pembelajaran, sehingga tidak memperhatikan siswa lain yang menyampaikan pendapatnya.

Kekurangan pada siklus I diperbaiki pada siklus II agar keaktifan dan hasil belajar siswa dapat meningkat sesuai indikator keberhasilan. Pada siklus II peneliti menjelaskan materi secara terperinci dan memberikan LKS kepada tiap-tiap siswa lebih meyakinkan siswa agar jangan malu untuk bertanya baik kepada guru atau teman yang lain dan menjawab pertanyaan-pertanyaan dari peneliti meskipun salah. Selain itu peneliti juga memancing siswa untuk mengungkapkan ide atau pikirannya dengan proses tanya jawab sesuai pendekatan talking stick.

Keaktifan siswa berdasarkan pengamatan mengalami peningkatan pada siklus II. Keaktifan semua siswa sudah dalam kategori baik atau sudah memenuhi indikator keberhasilan. Rerata keaktifan berdasarkan lembar observasi sebesar $85 \%$ dan prestasi belajar pada siklus II semua siswa sudah mencapai KKM sebanyak $90 \%$ dengan rata-rata nilai 85 .

Pada siklus II siswa sudah berani untuk mengungkapkan idenya tanpa tanpa malu-malu lagi. Kemampuan siswa dalam menyampaikan idenya juga semakin baik. Pada saat berdiskusi semua siswa mengerjakan tugas. Siswa lebih baik dalam bekerjasama dengan kelompoknya, dan siswa juga berani bertanya jika belum paham. Sehingga berdasarkan hasil penelitian pada siklus I dan II menunjukkan bahwa pendekatan pembelajaran talking stick dapat meningkatkan kemampuan keaktifan siswa dan berdampak pada peningkatan hasil belajar siswa pada materi yang disampaikan. Peningkatan keaktifan dan hasil belajar matematika siswa dapat diuraikan sebagai berikut.

a. Hasil Observasi Kemampuan Keaktifan Siswa Siklus I dan II

Berdarsarkan hasil observasi dengan menggunakan pendekatan talking stick, keaktifan siswa mengalami peningkatan dari siklus I ke siklus II. Pada 
pembelajaran menggunakan pendekatan talking stick guru memberikan kesempatan kepada siswa untuk membaca dan mempelajari materi pembelajaran dan berdiskusi membahas masalah. Siswa turut serta melaksanakan tugas belajarnya dengan baik. Siswa terlibat dalam pemecahan masalah/ diskusi dan mulai berani bertanya kepada siswa lain/ guru. Padasaat diskusi siswa berusaha mencari berbagai informasi yang diperlukan untuk pemecahan masalah dan melaksanakan diskusi kelompok sesuai dengan petunjuk guru. Siswa sadar apa yang perlu dilakukan untuk meningkatkan kemampuan dirinya dan melatih diri dalam memecahkan soal atau masalah yang sejenis sehingga menerapkan apa yang diperoleh dalam menyelesaikan tugas atau persoalan yang dihadapinya

b. Hasil belajar Matematika Siswa Tiap Siklus

Salah satu indikator keberhasilan dari penelitian ini adalah sebanyak $75 \%$ atau lebih dari jumlah seluruh siswa prestasi belajarnya telah mencapai KKM yaitu 75. Prestasi belajar siswa dapat dilihat dari hasil evaluasi pada tiap akhir siklus. Berikut disajikan data persentase prestasi belajar matematika siswa.

Tabel 7

Hasil Belajar Matematika Tiap Siklus

\begin{tabular}{|c|c|c|c|}
\hline Data & Prasiklus & Siklus I & Siklus II \\
\hline Rata-rata & 57 & 70 & 85 \\
\hline Ketuntasan & $50 \%$ & $70 \%$ & $90 \%$ \\
\hline
\end{tabular}

Berdasarkan Tabel 7 diketahui hasil belajar pada prasiklus diperoleh rata-rata 57 dengan ketuntasan 50\%. Kemudian pada siklus I rata-rata hasil belajar meningkat menjadi 70 dengan ketuntasan 70\%. Dan pada akhir siklus II hasil belajar matematika dicapai rata-rata 85 dengan ketuntasan $90 \%$. Berdasarkan hal tersebut menunjukkan peningkatan kamampuan keaktifan diikuti peningkatan prestasi belajar, artiunya pendekatan talking stick dalam penelitian dapat meningkatkan keaktifan dan hasil belajar siswa. Pada pembelajaran talking stick setiap siswa dituntut siap untuk menjawab pertanyaan yang diberikan. Hal ini memotivasi setiap siswa berusaha memahami materi pelajaran dan dapat menjawab 
STAINU Purworejo: Jurnal As Sibyan

Jurnal Kajian Kritis Pendidikan Islam

Vol 4 No 1 Januari - Juni 2021

dan Manajemen Pendidikan Dasar

Homepage: https://ejournal.stainupwr.ac.id/

Email: sibyan.stainupwrj@gmail.com

E-ISSN: : 2599-2732

setiap pertanyaan yang diberikan. Hal ini akan menambah pemahamannya terhadap materi pembelajaran sehingga dapat meningkatkan prestasi belajar matematika.

Hasil pembelajaran matematika pada siklus I dan II menggunakan model pembelajaran talking stick dapat disajikan dalam grafik berikut ini :

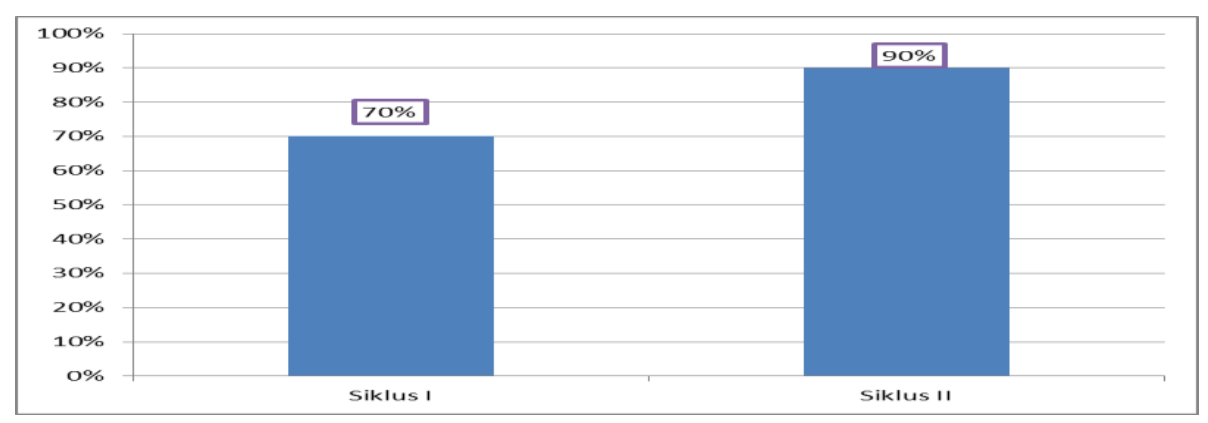

Gambar 5

Grafik Ketuntasan Pembelajar Matematika

Berdasarkan gambar 4 menunjukkan setelah dilakukan pembelajaran metemtika menggunakan model talking tick diperoleh 70\% siswa mencapai KKM pada siklus I dan pada siklus II ketuntasan pembelajaran meningkat menjadio $90 \%$ siswa mencapai KKM. Hasil ini sesuai dengan teori mretode pembelajaran yang diterapkan oleh guru merupakan salah satu factor yang mempengaruhi hasil belajar. Salah satu pendekatan yang dapat dipakai dalam pembelajaran adalah model pembelajaran talking stick. Pembelajaran talking stick merupakan pendekatan pembelajaran yang mengutamakan kerja sama kelompok dengan bantuan tongkat. Konsep pada pendekatan ini adalah kelompok yang memegang tongkat terlebih dahulu wajib menjawab pertanyaan dari guru setelah mempelajari materi pokoknya. Kegiatan ini diulang terus menerus sampai semua kelompok mendapat giliran untuk menjawab pertanyaan dari guru.

\section{KESIMPULAN}

Berdarkan hasil penelitian dan pembahasan, maka simpulan dari penelitian ini adalah. 
STAINU Purworejo: Jurnal As Sibyan

Jurnal Kajian Kritis Pendidikan Islam

Vol 4 No 1 Januari - Juni 202

dan Manajemen Pendidikan Dasar

Homepage: https://ejournal.stainupwr.ac.id/

Email: sibyan.stainupwrj@gmail.com

E-ISSN: : 2599-2732

1. Proses pembelajaran matematika menggunakan model pembelajaran talking stick pada siswa kelas IV MI Ma`Arif Kapulogo kepil Wonosobo tahun pelajaran 2020/2021 pada penelitian sebanyak dua siklus. Setiap siklus terdiri dari empat tahap yaitu perencanaan, pelaksanaan, pengamatan dan refleksi.

2. Penerapan model pembalajaran pendekatan talking stick dapat meningkatkan hasil belajar matematika siswa kelas IV MI Ma`Arif Kapulogo Kecamatan Kepil Kabupaten Wonosono. Hasil penelitian menunjukkan rata-rata hasil belajar matematika pada prasiklus adalah 57 dengan ketuntasan 50\%. Kemudian rata-rata hasil belajar matematika pada siklus meningkat menjadi 70 dengan ketuntasan $70 \%$ dan pada siklus II ratarata hasil belajar matematika meningkat menjadi 85 dengan ketuntasan 90\%. Dengan demikian model pembalajaran pendekatan talking stick dapat meningkatkan hasil belajar matematika siswa kelas IV MI Ma`arif Kapulogo Kecamatan Kepil Kabupaten Wonosono.

\section{DAFTAR PUSTAKA}

Agus Suprijono. (2020). Cooperative Learning.(Yogyakarta: Pustaka Pelajar.

Arikunto, Suharsimi. (2010) Penelitian Tindakan Kelas, Jakarta: Rineka Cipta.

Astuti, Cahya. (2017) Penerapan Model Pembelajaran Kooperatif Tipe talking stick Berbantuan Media Gambar Untuk Meningkatkan Hasil Belajar. (Wacana Akademika: Majalah Ilmiah Kependidikan. 1. 10.30738/wa.v1i2.999

Dwi Siswoyo, dkk. (2011) Ilmu Pendidikan, Yogyakarta: UNY Press

Miftahul Huda. (2017). Model-Model Pengajaran dan Pembelajaran, Yogyakarta. Pustaka Pelajar,

Mulyasa. (2013) Pengembangan Implementasi Kurikulum,. Bandung: PT. Remaja Karyaja Rosda Karya

Ngalim Purwanto. (2011) Psikologi Pendidikan. Bandung: PT. Remaja Karyaja Rosda Karya

Rendi Lilit Iman Pambudi, (2016) Penerapan Model Pembelajaran talking stick Untuk Meningkatkan Hasil Belajar Matematika Pada Siswa Kelas IV SD Negeri Suryodiningratan II Tahun Ajaran 2015/2016, Yogyakarta: PGSD-S1 Universitas Negeri Yogyakarta 
STAINU Purworejo: Jurnal As Sibyan Jurnal Kajian Kritis Pendidikan Islam

\section{dan Manajemen Pendidikan Dasar}

Homepage: https://ejournal.stainupwr.ac.id/

Email: sibyan.stainupwrj@gmail.com

E-ISSN: : 2599-2732

Rusmono, 2014. Strategi Pembelajaran dengan Problem Based Learning Itu Perlu. Jakarta: Ghalia Indonesia

Slameto. (2013) Belajar dan Faktor-faktor yang Mempengaruhinya. Jakarta: Rineka Cipta

Sugiyono, (2015) Metode Penelitian Pendidika Bandung: Alfabeta, 2015.

Syaiful Bahri Djamarah, (2012) Psikologi Belajar, Jakarta: PT Rineka Cipta,

Syaiful Bahri Djamarah (2015). Psikologi Belajar.Jakarta: Rineka Cipta

Widoyoko, Eko Putra. (2013) Evaluasi Program Pembelajaran Panduan Praktis bagi Pendidikan dan Calon Pendidik. Yogyakarta: Pustaka Pelajar

www.rumahbangsa.net/ 2014/07/masalah-yang-dihadapi-siswa-sekolah). 